ТЕРАПЕВТИЧНА СТОМАТОЛОГІЯ

УДК 616.314.17-085.275.4

DOI 10.11603/2311-9624.2018.1.8579

(C). О. Гевкалюк

дВНЗ «Тернопільський державний медичний університет імені І. Я. Горбачевського»

\title{
Фітопрепарат «Ресверазин» у комплексному лікуванні генералізованого пародонтиту
}

Резюме. Високе поширення, несприятливий вплив вогнищ пародонтальної інфекції на стан порожнини рота визначають актуальність проблеми застосування фітопрепаратів у комплексному лікуванні генералізованого пародонтиту.

Мета дослідження - оцінити клінічну ефективність препарату «Ресверазин» у складі комплексного лікування генералізованого пародонтиту.

Матеріали і методи. У дослідженні брали участь 43 пацієнти, хворі на хронічний генералізований пародонтит початкового та І ступенів. Основну групу склали 25 осіб, групу порівняння - 18. Для оцінки гігієнічного стану порожнини рота використовували індекси Green-Wermillion, OHI-S, Silness-Loe, Stallard. Оцінку стану пародонта проводили за клінічними ознаками; тяжкість гінгівіту визначали за індексом PMA, стан ясен - за індексом кровоточивості Muhlleman, ступінь деструктивних змін у пародонті - за пародонтальним індексом (ПІ). Для лікування пародонтиту в пацієнтів обох груп використовували традиційну терапію. Пацієнтам основної групи призначали ресверазин по 1 капсулі 2 рази на добу після їжі. Курс лікування становив 2 місяці.

Результати досліджень та їх обговорення. При об’єктивному обстеженні, проведеному до початку

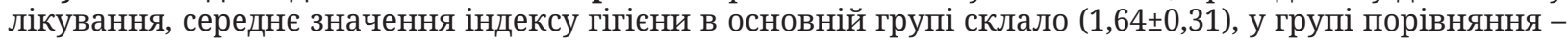
$(1,59 \pm 0,23)$ бала. Індекс РМА в основній групі становив $(63,12 \pm 1,17)$, у групі порівняння - $(62,39 \pm 1,13)$ бала. Індекси OHI-S, Silness-Loe та Stallard у пацієнтів основної групи були $(2,36 \pm 0,13),(1,54 \pm 0,08)$, $(1,2 \pm 0,062)$ бала, у групі порівняння - $(2,30 \pm 0,12),(1,51 \pm 0,06)$ та $(0,89 \pm 0,032)$ бала відповідно. Значення ПI та індексу Muhlleman у групах були $(1,22 \pm 0,09)$ i $(2,21 \pm 0,13)$ та $(1,24 \pm 0,13)$ i $(2,18 \pm 0,11)$ бала відповідно. В процесі лікування спостерігали позитивну динаміку досліджуваних показників. Значення індексу

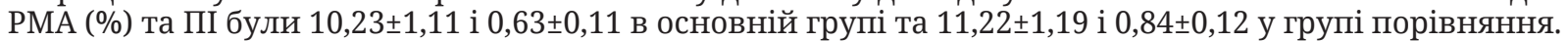

Висновки. Отримані результати підтверджують високу клінічну ефективність натурального комплексу «Ресверазин», включення якого в схему базисної терапії генералізованого пародонтиту сприяє позитивній динаміці та стабільним змінам в тканинах пародонта.

Ключові слова: фітопрепарати; ресверазин; генералізований пародонтит.

\section{(Н. А. Гевкалюк}

ГВУз «Тернопольский государственный медицинский университет имени И. Я. Горбачевского»

\section{Фитопрепарат «Ресверазин» в комплексном лечении генерализованного пародонтита}

Резюме. Высокая распространенность, неблагоприятное влияние очагов пародонтальной инфекции на состояние полости рта определяют актуальность проблемы использования фитопрепаратов в комплексном лечении генерализованного пародонтита.

Цель исследования - оценить клиническую эффективность препарата «Ресверазин» в составе комплексного лечения генерализованного пародонтита.

Материалы и методы. В исследовании принимали участие 43 пациентов, больных хроническим генерализованным пародонтитом начальной и I степеней. Основную группу составили 25 человек, группу сравнения - 18. Для оценки гигиенического состояния полости рта использовали индексы Green-Wermillion, OHI-S, Silness-Loe, Stallard. Оценку состояния пародонта проводили по клиническим признакам; тяжесть гингивита определяли по индексу РМА, состояние десен - по индексу кровоточивости Muhlleman, степень деструктивных изменений в пародонте - по пародонтальном индексу (Пи). Для лечения пародонтита у пациентов обеих групп использовали традиционную терапию. Пациентам основной группы назначали ресверазин по 1 капсуле 2 раза в сутки после еды. Курс лечения составлял 2 месяца.

Результаты исследований и их обсуждение. При объективном обследовании, проведенном до начала лечения, среднее значение индекса гигиены в основной группе составило $(1,64 \pm 0,31)$, в группе сравнения - $(1,59 \pm 0,23)$ балла. Индекс РМА в основной группе составлял $(63,12 \pm 1,17)$, в группе сравнения - $(62,39 \pm 1,13)$ балла. Индексы OHI-S, Silness-Loе и Stallard у пациентов основной группы состав- 
ляли $(2,36 \pm 0,13),(1,54 \pm 0,08),(1,2 \pm 0,062)$ балла, в группе сравнения - $(2,30 \pm 0,12),(1,51 \pm 0,06)$ и $(0,89 \pm 0,032)$ балла соответственно. Значения ПИ и индекса Muhlleman в группах составили $(1,22 \pm 0,09),(2,21 \pm 0,13)$ и $(1,24 \pm 0,13),(2,18 \pm 0,11)$ балла соответственно. В процессе лечения наблюдалась положительная ди-

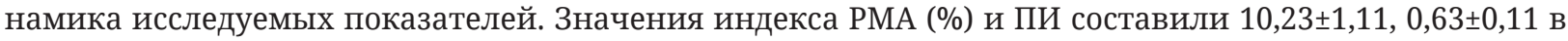
основной группе и 11,22 $\pm 1,19,0,84 \pm 0,12$ в группе сравнения.

Выводы. Полученные результаты подтверждают высокую клиническую эффективность натурального комплекса «Ресверазин», включение которого в схему базисной терапии генерализованного пародонтита способствует положительной динамике и стабильным изменениям в тканях пародонта.

Ключевые слова: фитопрепараты; ресверазин; генерализованный пародонтит.

\section{(C) N.O. Hevkaliuk}

I. Horbachevsky Ternopil State Medical University

\section{Herbal medicinal product Resverazin in the complex treatment of generalized periodontitis}

Summary. High prevalence, unfavorable effects of periodontal infection centers on the oral cavity condition determine the relevance of the problem of the use of phytopreparations in the treatment of generalized periodontitis.

The aim of the study - to evaluate the clinical efficacy of the drug Resverazin in the complex treatment of generalized periodontitis.

Materials and Methods. The study was attended by 43 patients, patients with chronic generalized periodontitis of primary and stage I. The main group was 25 people, the comparison group was 18 . To assess the hygienic state of the cavity, the indices Green-Wermillion, ONI-S, Silness-Loe, Stallard were used. The assessment of the periodontal condition was conducted according to clinical signs; the severity of gingivitis was determined by the PMA index, the state is clear - according to the index of bleeding Muhlleman, the stages of destructive changes in the periodontium - according to the periodontal index (PI). For the treatment of periodontitis in both groups, traditional therapy was used. The patients in the main group were prescribed Resverazin for 1 capsule 2 times a day after eating. The course of treatment was 2 months.

Results and Discussion. In an objective survey conducted before treatment, the average value of the index of hygiene in the main group was $(1.64 \pm 0.31)$, in the comparison group - $(1.59 \pm 0.23)$ points. The PMA index in the main group was $(63.12 \pm 1.17)$, in the comparison group - $(62.39 \pm 1.13)$ points. The ONI-S, Silness-Loe and Stallard indexes in the patients in the main group were $(2.36 \pm 0.13),(1.54 \pm 0.08),(1.200 \pm 0.062)$ points, in the comparison group - $(2.30 \pm 0.12),(1.51 \pm 0.06)$ and $(0.890 \pm 0.032)$ points, respectively. The values of PI and the Muhlleman index in the groups were $(1.22 \pm 0.09)$ and $(2.21 \pm 0.13)$ and $(1.24 \pm 0.13)$ and $(2.18 \pm 0.11)$ points, respectively. During the treatment, a positive dynamics of the studied parameters was observed. The values of the PMA index $(\%)$ and PI were $(10.23 \pm 1.11)$ and $(0.63 \pm 0.11)$ in the main group and $(11.22 \pm 1.19)$ and $(0.84 \pm 0.12)$ in the comparison group.

Conclusions. The obtained results confirm the high clinical efficiency of the natural complex Resverazin, the inclusion of which in the scheme of basic therapy of generalized periodontitis contributes to positive dynamics and stable changes in the tissues of periodontal disease.

Key words: herbal medicinal products; Resverazin; generalized periodontitis.

Вступ. Хвороби пародонта належать до найпоширеніших захворювань людства. За даними В003, від 55 до 98 \% дорослого населення планети має патологію пародонта, причому найвищий рівень захворюваності припадає на осіб віком 35-44 років (65-98 \%) [3]. Високе поширення, несприятливий вплив вогнищ пародонтальної інфекції на стан порожнини рота та організм у цілому, високий рівень ускладнень визначають актуальність даної проблеми.
Відомо, що ротова порожнина є збалансованою біологічною системою, порушення рівноваги в якій між бактеріальним симбіозом та резистентністю тканин ротової порожнини сприяє розвитку захворювань пародонта [2, 7, 10]. Мікроорганізми ротової порожнини - анаероби та грамнегативні бактерії, проникаючи вглиб тканин, виділяють ендотоксини, ферменти та продукти життєдіяльності, виявляють агресивну дію в ділянці бактеріальної інвазії. Все це зумовлює порушення клітинного 
обміну, проникності епітелію ясенної боріздки, вазомоторні розлади, збільшення проникності капілярів, сприяючи виходу плазмових та клітинних медіаторів запалення [5, 8].

Під впливом біологічно активних речовин відбуваються розлади в мікроциркуляції: сповільнюється кровотік, зростає в'язкість крові, виникає васкуліт. Підвищенню судинно-тканинної проникності спричиняє вихід плазмових білків за межі судин у периваскулярні тканини. Внаслідок цього підвищується активність колагенази та еластази, спричиняючи руйнування колагену, епітеліального прикріплення, колагенових волокон кругової зв'язки зуба. В тканинах пародонта відбуваються виражені деструктивні зміни із залученням у патологічний процес кісткової тканини, що призводить до оголення коренів зубів, їх розхитування, до передчасної втрати зубів, порушення функції жування та значних змін в зубощелепній системі [2, 3]. Хвороби пародонта справляють негативний вплив на організм людини в цілому, тому захворювання тканин пародонта на сьогодні є загальномедичною проблемою.

Великий арсенал препаратів, які застосовують при лікуванні захворювань пародонта, складають лікарські засоби синтетичного походження, які поряд із вираженою позитивною дією можуть спричинити численні побічні ефекти. У зв'язку з цим, в останні роки увагу дослідників привертають лікарські препарати рослинного походження, що зумовлено низькою токсичністю, відносною безпечністю фітопрепаратів, і дозволяє рекомендувати їх для широкого симптоматичного та базового лікування $[1,4,6]$. Різноманітний діапазон фармакологічної дії фітопрепарату «Ресверазин» визначив наш вибір його в якості етіотропного, патогенетичного та симптоматичного лікування хворих на генералізований пародонтит [9].

Метою дослідження було оцінити клінічну ефективність препарату «Ресверазин» у складі комплексного лікування генералізованого пародонтиту.

Матеріали і методи. У дослідженні брали участь 43 пацієнти, хворі на хронічний генералізований пародонтит (ГП) початкового та I ступенів (23 чоловіків та 20 жінок), 3 яких були сформовані дві групи. Основну групу склали 25 чоловік, групу порівняння - 18. При обстеженні 32 пацієнтів пред’являли скарги на набряк та кровоточивість ясен, яка поси- лювалась при чищенні зубів і прийомі твердої їжі, біль у яснах, 12 хворих скаржились на естетичний дефект, оголення шийок і коренів зубів, рухомість зубів, неприємний запах з рота, у 9 пацієнтів скарги були відсутні.

Для оцінки гігієнічного стану порожнини рота використовували індекси GreenWermillion, OHI-S, Silness-Loe, Stallard. Оцінку стану пародонта проводили за такими клінічними ознаками: кольором, формою, розміром ясенних сосочків, наявністю кровоточивості при пальпації та зондуванні ясенної борозни, визначали цілість зубоясенного з'єднання. Для оцінки тяжкості хронічного катарального гінгівіту і реєстрації динаміки процесу використовували РМА, рекомендований ВОО3, при обстеженні стану тканин пародонта. Стан ясен вивчали за індексом кровоточивості за Muhlleman. Для оцінки ступеня деструктивних змін у пародонті використовували пародонтальний індекс (ПІ), визначення глибини пародонтальних кишень. Визначення і підрахунок індексів проводили за загальноприйнятими методиками.

Для місцевого лікування пародонтиту в пацієнтів обох груп використовували традиційну терапію. Загальне лікування передбачало лікування фонових захворювань. Загальнозміцнювальна терапія полягала в призначенні вітамінів С, Р, групи В. Призначали препарати кальцію, фосфору та гіпосенсибілізувальні препарати. Пацієнтам основної групи призначали препарат «Ресверазин» по 1 капсулі 2 рази на добу після їжі, запиваючи достатньою кількістю питної води. Курс лікування становив 2 місяці.

Результати досліджень та їх обговорення. При об’єктивному обстеженні, проведеному до початку лікування, у пацієнтів основної та контрольної груп було виявлено незадовільний стан гігієни порожнини рота і тканин пародонта. Середнє значення індексу гігієни в основній групі склало (1,64ะ0,31); а в групі порівняння - $(1,59 \pm 0,23)$ бала. Індекс РМА в основній групі обстежених становив $(63,12 \pm 1,17)$ бала; в групі порівняння - $(62,39 \pm 1,13)$ бала. Гігієнічні індекси OHI-S та Silness-Loe у пацієнтів основної групи становили $(2,36 \pm 0,13)$ та $(1,54 \pm 0,08)$ бала, у групі порівняння - $(2,30 \pm 0,12)$ та $(1,51 \pm 0,06)$ бала відповідно. Індекс Stallard у пацієнтів основної групи складав $(1,2 \pm 0,062)$ бала, в групі порівняння - $(0,89 \pm 0,032)$. Значення

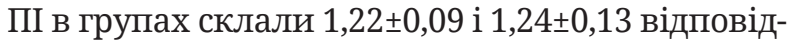
но. Середнє значення індексу Muhlleman по гру- 
пах становило $(2,21 \pm 0,13)$ бала в основній групі та $(2,18 \pm 0,11)$ бала у групі порівняння.

У процесі лікування в усіх пацієнтів спостерігали позитивну динаміку досліджуваних показників. Так, динаміка показника поширеності запалення тканин пародонта (індекс PMA) мала тенденцію до зменшення ознак запалення, що підтвердилось клінічними методами та суб’єктивними даними. Значення індексу РМА (\%) після закінчення курсу лікування склало 10,23 $\pm 1,11$ в основній групі та $11,22 \pm 1,19$ у групі порівняння. Після закінчення курсу лікування у 24-х пацієнтів основної групи відмічались ознаки стабілізації пародонтиту. В одного пацієнта було помірне запалення міжзубних сосочків у ділянці зубів, покритих штучними коронками, пов'язане із недостатнім гігієнічним доглядом за порожниною рота. В групі порівняння після закінчення курсу лікування в 15-ти пацієнтів зберігались клінічні ознаки стабілізації тканин пародонта. У трьох осіб було виявлено гіперемію, набряк та кровоточивість міжзубних сосочків.

Аналогічна тенденція простежувалась при вивченні динаміки пародонтального індексу: в основній групі його значення зменшилось і становило $0,63 \pm 0,11$, у групі порівняння

\section{Список літератури}

1. Рациональная фармакотерапия в стоматологии / [Г. М. Барер, Е. В. Зорян, В. С. Агапов и др.]. - М. : Медицина, 2010. - С. 235-245.

2. Безрукова И. В. Микробиологические и иммунологические аспекты этиопатогенеза быстропрогрессирующего пародонтита : обзор литературы / И. В. Безрукова // Пародонтология. 2005. - № 3. - C. 22-25.

3. Канканян А. П. Болезни пародонта : новые подходы в этиологии, патогенезе, диагностике, профилактике и лечении / А. П. Канканян, В. К. Леонтьев. - Ер. : Тигран мец. - 2010. - 360 с.

4. Кукес В. Г. Фитотерапия с основами клинической фармакологии / В. Г. Кукес. - М. : Медицина, 1999. 189 c.

5. Луцкая И. К. Болезни пародонта / И. К. Луцкая. М. : Мед. литература, 2010. - 243 с.

6. Антиоксидантные свойства биофлаваноидов

\section{References}

1. Barer, G.M., Zoryan, E.V., \& Agapov, V.S. (2010). Ratsionalnaya farmakoterapiya $v$ stomatologii [Rational pharmacotherapy in dentistry]. Moscow: Meditsina [in Russian].

2. Bezrukova, I.V. (2005). Mikrobiologisheskie i immunologisheskie aspekty etiopatogeneza bystroprogressiruyushchego parodontita (obzor literatury) [microbiological and immunological aspects of etio-

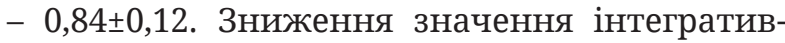
ного пародонтального індексу відбувалось переважно за рахунок зменшення тяжкості симптоматичного гінгівіту та глибини пародонтальних кишень. Однак, якщо в основній групі після закінчення лікування достовірних змін пародонтального індексу відмічено не було, то в групі порівняння з'явилась тенденція до півищення значення ПІ.

Висновки. Отримані результати дозволяють зробити висновок про високу клінічну ефективність натурального комплексу препарату «Ресверазин», діапазон фармакологічної дії якого мав вирішальне патогенетичне значення в перебігу генералізованого пародонтиту. Включення препарату в схему базисної терапії генералізованого пародонтиту сприяє настанню позитивної динаміки та стабільних змін у тканинах пародонта в більш ранні терміни, що підтверджується позитивними змінами пародонтальних індексів.

Перспективи подальших досліджень. Подальші дослідження будуть спрямовані на вивчення фармакологічного ефекту фітопрепарату «Рестверазин», а саме, антиоксидантного, притизапального, антиангіогенного при перебігу генералізованого пародонтиту.

цитрусовых / О. А. Макаренко, Л. Н. Россаханова, И. И. Крисюн [и др.] // Вісник стоматології. - 2011. № 4. - С. 26-27.

7. Руденко В. В. До проблеми запальних захворювань порожнини рота / В. В. Руденко // Український медичний часопис. - 2005. - № 2. - С. 110-112.

8. Das S. Anti-inflammatory responses of resveratrol / S. Das, D. K. Das // Inflamm. Allergy Drug Targets. - 2007. Vol. 6 (3). - P. 168-173.

9. Khazaei S. Resveratrol as a supplemental treatment for periodontitis / S. Khazaei // Dent. Res. J. (Isfahan). 2012. - Vol. 9 (5). - P. 655-657.

10. Surna A. Microbiological and biochemical characteristics of inflammatory tissues in the periodontium / A. Surna, J. Sakalauskiene, A. Vitkauskiene // Medicina (Kaunas). - 2009. - Vol. 44, No. 3. - P. 201-210.

pathogenesis of fast-progressing periodontitis (review of literature)]. Parodontologiya - Parodontology, 3, 22-25 [in Russian].

3. Kankanyan, A.P., \& Leontyev, V.K. (2010). Bolezni parodonta: novye podkhody $v$ etiologii, patogenezi, diagnostike, profilaktike i lechenii [Periodontal diseases: New approaches in etiology, pathogenesis, diagnosis, prevention and treatment]. Er. Tigran mets. [in Russian]. 


\section{Терапевтична стоматологія}

4. Kukes, V.G.(1999). Fitoterapiya s osnovami klinicheskoy farmakologii [Phytotherapy with the basics of clinical pharmacology]. Moscow: Meditsina [in Russian].

5. Lutskaya, I.K. (2010). Bolezni parodonta [Periodontal diseases]. Moscow: Med. Literature [in Russian].

6. Makarenko, O.A., Rossakhanova, L.N., \& Krisyun, I.I., Pustovoyt, E.P. \& Dvulit, I.P. (2011). Antioxidantnye svoystva bioflavonoidov tsitrusovykh [Antioxidant properties of citrus bioflavonoids]. Visnyk stomatolohii - Journal of Dentistry, 4, 26-27 [in Russian].

7. Rudenko, V.V. (2005). Do problem zapalnykh zakhvoriuvan porozhnyny rota [To the problem of inflammatory diseases of the cavity of the mouth].
Ukrainskyi medychnyi chasopys - Ukrainian Medical Journal, 2, 110-112 [in Ukrainian].

8. Das, S., \& Das, D.K. (2007). Anti-inflammatory responses of resveratrol. Inflamm. Allergy Drug Targets, 6 (3), 168-173.

9. Saber Khazaei (2012). Resveratrol as a supplemental treatment for periodontitis. Dent. Res. J. (Isfahan), 9 (5), 655-657.

10. Surna, A., Sakalauskiene, J., \& Vitkauskiene, A. (2009). Microbiological and biochemical characteristics of inflammatory tissues in the periodontium. Medicina (Kaunas), 44 (3), 201-210.

Отримано 02.10.17 